\title{
Construction and validation of an educational booklet on care for children with gastrostomy
}

\author{
Construção e validação de cartilha educativa sobre cuidados para crianças com gastrostomia \\ Construcción y validación del folleto educativo para el cuidado de niños con gastrostomía
}

Lidiane do Nascimento Rodrigues'
ORCID: 0000-0003-1503-4855
Aliniana da Silva Santos'
ORCID: 0000-0002-1742-2758
Priscila Pereira de Souza Gomes'
ORCID: 0000-0001-8743-145X
Wandra Camila Penaforte da Silva'
ORCID: 0000-0002-4841-2886
Edna Maria Camelo Chaves'
ORCID: 0000-0001-9658-0377

'Universidade Estadual do Ceará. Fortaleza, Ceará, Brazil.

How to cite this article:

Rodrigues LN, Santos AS, Gomes PPS, Silva WCP,

Chaves EM. Construction and validation of an educational booklet on care for children with gastrostomy. Rev Bras Enferm. 2020;73(3):e20190108. doi: http://dx.doi.org/10.1590/0034-7167-2019-0108

Corresponding author:

Lidiane do Nascimento Rodrigues E-mail: lidianerodrigues09@gmail.com

EDITOR IN CHIEF: Antonio José de Almeida Filho ASSOCIATE EDITOR: Elucir Gir

Submission: 02-15-2019 Approval: 04-26-2019

\begin{abstract}
Objectives: to describe the process of construction and validation of an educational booklet on care for children with gastrostomy, directed to caregivers. Methods: a methodological study developed in five stages: bibliographic survey; situational diagnosis; illustration, layout, design and text construction; expert validation and Flesch-Kincaid Readability calculation; validation with the target audience. Content Validity Index and Suitability Assessment of Materials were applied for expert analysis. Results: the Content Validity Index obtained overall score of 0.93 . In the Suitability Assessment of Materials score, the booklet scored $85.2 \%$. It presented a satisfactory readability percentage, with an overall score of $72 \%$, and was consistent with caregivers' assessment in the validation with the target audience, considering the explanatory technology, important and adequate. Conclusions: the developed educational booklet was considered valid for use by caregivers, thus contributing to the maintenance of best practices in care for children with gastrostomy.

Descriptors: Child Care; Gastrostomy; Educational Technology; Pediatric Nursing; Health Education.
\end{abstract}

\section{RESUMO}

Objetivos: descrever o processo de construção e validação de uma cartilha educativa direcionada a cuidadores sobre cuidados para crianças com gastrostomia. Métodos: estudo metodológico desenvolvido em cinco etapas: levantamento bibliográfico; diagnóstico situacional; construção das ilustrações, layout, design e textos; validação com especialistas e cálculo do Índice de Legibilidade de Flesch; e validação com o público-alvo. Na etapa de análise dos especialistas, foram aplicados o Índice de Validade de Conteúdo e o instrumento Suitability Assessmente of Materials. Resultados: o Índice de Validade de Conteúdo obteve escore global de 0,93 e, no escore Suitability Assessmente of Materials, a cartilha alcançou pontuação de $85,2 \%$. Obtevese percentual de legibilidade satisfatório, com pontuação global de $72 \%$. O material educativo construído foi considerado coerente com a avaliação das cuidadoras na validação com o públicoalvo, além de explicativo, importante e adequado. Conclusões: a cartilha educativa desenvolvida foi considerada válida para ser utilizada pelos cuidadores e poderá contribuir para a manutenção de boas práticas nos cuidados da criança com gastrostomia.

Descritores: Cuidado da Criança; Gastrostomia; Tecnologia Educacional; Enfermagem Pediátrica; Educação em Saúde.

\section{RESUMEN}

Objetivos: describir el proceso de creación y validación de un folleto educativo para cuidadores sobre el cuidado de niños con gastrostomía. Métodos: estudio metodológico desarrollado en cinco etapas: encuesta bibliográfica; diagnóstico situacional; construcción de ilustraciones, maquetación, diseño y textos; validación experta y cálculo del índice de legibilidad de Flesch; y validación con la audiencia. En la etapa de análisis experto, se aplicaron el Índice de Validez del Contenido y el instrumento. Suitability Assessmente of Materials. Resultados: el Índice de Validez del Contenido obtuvo una puntuación global de 0,93 y, en la puntuación Suitability Assessmente of Materials, el cebador alcanzó una puntuación del $85,2 \%$. Se obtuvo un porcentaje de legibilidad satisfactorio, con una puntuación general del $72 \%$. El material educativo construido se consideró coherente con la evaluación de los cuidadores en la validación con el público objetivo, además de ser explicativo, importante y adecuado. Conclusiones: el folleto educativo desarrollado se consideró válido para su uso por los cuidadores y puede contribuir al mantenimiento de buenas prácticas en el cuidado de niños con gastrostomía.

Descriptores: Cuidado del Niño; Gastrostomía; Tecnología Educacional; Enfermería Pediátrica; Educación en Salud. 


\section{INTRODUCTION}

Gastrostomy is commonly used to replace the oral feeding route of children with neurological disorders, esophageal atresia or as a caloric intake to correct inborn metabolism, and may be temporary or definitive use $\mathrm{e}^{(1)}$. It can be understood as a type of stoma in which a polyurethane or silicone flexible tube is introduced into the stomach by a surgical procedure performed on the abdominal wall or endoscopically ${ }^{(1)}$.

They depend on this medical technology to survive, therefore children with gastrostomy have special health needs. They also need caregivers, who undergo various modifications and adaptations in their routine, as they assume responsibility for performing daily care such as bath, food and medications ${ }^{(2)}$.

From the surgical procedure, the guidance provided by health professionals to caregivers should be clear and well explained, as studies indicate that they have difficulties in dealing with this child at home ${ }^{(3-4)}$. Research has also reported that it is necessary to develop an effective health education program to assist caregivers in the proper transition to home management of the gastrostomy catheter on an ongoing basis. Handling should be used prior to hospital discharge, with support from health staff(2-5).

Health education aims to socialize knowledge, health promotion and disease prevention, especially with regard to chronic diseases ${ }^{(6)}$. Of the various educational procedures available, the use of printed educational technologies is considered a viable tool for informing and sensitizing the population. This tool opens new paths for health promotion, in a shared construction of knowledge between professionals and population, and allows the use of new resources in care $^{(7)}$.

Nurses have been using these technologies in the health education process, given the ease they provide for mediating teaching and learning. It is also a resource readily available for children and their families to consult with in the face of doubts in the development of care delivery ${ }^{(8)}$.

In this context, the process of construction and validation of educational technologies - such as booklet-that bring together scientific knowledge and care practice, has been a widely used method to develop health education actions ${ }^{(9)}$. However, for a tool to be considered valid, it must be previously submitted to a validation process with professionals considered experts in the subject. It should be approved in order to ensure the quality of the material produced ${ }^{(10)}$.

In this case, educational booklet use stems from the need to provide written materials to support care for children with gastrostomy at home that are relevant to the practice of caregivers and avoid future complications with the catheter. Therefore, considering the gaps between knowledge and practice in children care, the following questions emerged: which domains should compose a booklet on care for children with gastrostomy? Does the elaborate booklet have valid content and appearance for use by caregivers according to experts?

\section{OBJETIVES}

To describe the process of construction and validation of an educational booklet on care for children with gastrostomy, directed to caregivers.

\section{METHODS}

\section{Ethical aspects}

The project that originated this study was submitted and approved by the Research Ethics Committee of Hospital Infantil Albert Sabin, under opinion number 1.960.144 and CAAE (Certificado de Apresentação para Apreciação Ética - Certificate of Presentation for Ethical Consideration) 65296217.4.0000.5042. It complied with Resolution 466/12 of the Brazilian National Health Board (Conselho Nacional de Saúde). All research participants signed the Informed Consent Form.

\section{Methodological design and study stages}

This is a methodological research developed in five steps: 1. bibliographic survey; 2 . situational diagnosis; 3 . illustration, layout, design and text construction; 4. expert validation and Flesch-Kincaid Readability (FKR) calculation; and 5. validation with the target audience.

The first stage of the study took place from February to March 2017, with the bibliographic survey through an integrative review, performed by two researchers independently, in the Latin American \& Caribbean Health Sciences Literature (LILACS - Literatura Latino-Americana e do Caribe em Ciências da Saúde); Medical Literature Analysis and Retrieval System Online (MEDLINE) and Cumulative Index to Nursing and Allied Health Literature (CINAHL) and Scientific Electronic Library Online (SciElo) databases. For article selection, we used the health terminology consulted in the Descritores em Ciência da Saúde (DeCS - Health Science Descriptors) and the Medical Subject Headings (MeSH). The controlled descriptors used were "gastrostomy", "children care" and "nursing", associated with each other using the Boolean operator AND.

The second stage, situational diagnosis, was performed in order to know the population for which the constructed material is intended. Twenty-nine caregivers of children with gastrostomy who attended a service specialized in ostomy, incontinence and wounds from March to April 2017, selected by convenience, participated in this stage. Interviews were conducted with the help of a semistructured script containing questions about sociodemographic and clinical data of caregivers and children with gastrostomy, as well as questions related to gastrostomy management actions. The answers obtained in the interviews were recorded and organized into themes to support booklet construction.

In the third stage, illustrations and preliminary content were developed and submitted to editing and diagramming. They met the criteria related to content, structure/organization, language, layout and design, cultural sensitivity and suitability for the pediatric audience, by a designer with extensive experience in creating children's characters. Images were selected from the internet and then converted to drawing and worked on the Corel Draw software, version 17, resulting in the first version of the booklet submitted for validation.

Tool validity also depends on the approval of experts considered experts on the subject ${ }^{(11)}$. Then, in the fourth step, the material constructed was validated by consulting experts in the area of interest, distributed in two distinct categories: 18 content experts 
(researchers/professors in the field of child health, gastrostomy, educational technologies and/or tool validation) and five technical experts (professionals with professional design experience)). After expert analysis, the booklet was sent for Portuguese proofreading and then the readability index was assessed using the ReGra program in Microsoft Word, version 2010.

The fifth step was the booklet' second version assessment by the target audience. Caregivers of children with gastrostomy admitted to Hospital Infantil Albert Sabin (HIAS) in October 2017 participated in this stage. They received the booklet and answered a form with 13 questions that sought to capture their opinions on the organization, writing style, appearance and motivation for learning provided by the booklet built ${ }^{(12)}$. At the end of the presentation, the participants' opinion on the booklet was requested.

\section{Population/sample; inclusion and exclusion criteria}

Given the heterogeneity of references and the lack of standardization to determine the expert profile, the criteria for participating in validation process in the fourth step were elaborated by the researchers. For content validation, we considered as experts the evaluators who scored at least five points out of 15 , according to the following criteria: doctoral degree (3 points); master degree ( 2 points). In both cases, they should have a thesis and/or dissertation in the area of pediatrics, gastrostomy or educational technology (area of interest); scientific production in the area of interest (2 points); minimum one year care practice with children with gastrostomy (3 points); specialization in stomatherapy, dermatology or child health (2 points); participation in gastrostomy or child health events ( 1 point); and minimum experience of one year in validating educational tools or materials (2 points).

For technical experts, those with at least three out of ten points were included, according to the established criteria: minimum experience of one year in the area of designer and marketing ( 3 points); Communication degree (3 points); graduate degree in Communication ( 2 points); and minimum experience of one year in validating educational tools or materials ( 2 points).

Sample size was calculated by the formula: $\mathrm{n}=\mathrm{Za2.P}(1-\mathrm{P}) /$ e2. "P" represents the expected proportion of experts, indicating the suitability of each item, and " $\mathrm{e}$ " represents the acceptable proportional difference from what is expected. The following values were considered for the calculation: $\mathrm{Za2}=1.96 ; \mathrm{P}=0.85$; $\mathrm{e}=0.15$, which resulted in 22 experts ${ }^{(13)}$.

The search for the experts took place for convenience by snowball sampling ${ }^{(14)}$. Thus, when a expert was appointed, the Lattes Platform was searched to assess if it met the pre-established criteria, aiming at a subsequent invitation to study. Content expert selection was initiated with health professionals from the expert service for ostomy, incontinence and wound care at Hospital Infantil Albert Sabin and technical experts by inviting them to a higher education institution. Thus, from the first expert, other professionals were asked to compose the sample.

Contact took place electronically or in person, with the assessment tool being sent to 33 professionals who agreed to participate, of which 28 were content experts and five technicians. Of these, 23 returned the tool answered, with an average return of 14 days. Thus, the final sample of 23 experts who met the eligibility criteria was considered. Eighteen health professionals participated in the validation process as content experts and five as technical experts. Of the experts who participated in the validation, 12 did so via email and 11 received the tools printed and delivered in envelopes.

In the validation phase of the booklet with the target audience, ten caregivers of children with gastrostomy participated, a number described in the literature as the minimum number of informants ${ }^{(15)}$. In this case, the inclusion criteria were: 1 ) being the caregiver of a child with gastrostomy; 2 ) being 18 years old or older; 3 ) being literate, i.e., having at least four years of study. The exclusion criterion adopted was presenting a compromised physical or mental health condition, which would make the assessment of the booklet unfeasible.

\section{Study protocol}

After consent to participate in the research and assessment of educational material, the 33 professionals were delivered: Standard Operating Procedure (SOP), containing the necessary instructions for the operation of the expert role; Informed Consent; assessment tool and educational booklet. A deadline of 15 days was established for the return of the assessed tools, being extended for another 15 days for those who did not return them. It is noteworthy that ten professionals did not return the answered tool within 30 days and, therefore, were excluded from the study.

Content experts assessed the booklet for the objectives, structure, presentation, and relevance of the items ${ }^{(16)}$. For this assessment, the inverted Likert scale with five valuation levels was used: $1=1$ strongly disagree; 2 = I disagree; 3 = I neither agree nor disagree; 4 $=\mathrm{I}$ agree; 5 = I totally agree. For options marked 1 and 2 , justifications were requested and, subsequently, the items were reviewed by the researchers, leaving them with the decision to keep them or not in the prepared booklet. Items marked with option " 3 " were not considered for analysis, as they express neutrality of valuation.

Technical experts analyzed the booklet using a questionnaire on content, language, graphic illustrations, motivation and cultural suitability ${ }^{(17)}$ This assessment included three valuation levels: 1 = inadequate; 2 = partially adequate; 3 = adequate. After incorporating the experts' suggestions, accepted by the researchers, FKR was calculated, which refers to the reader's level of education required to understand the writing ${ }^{(18)}$. In this analysis, the author considers the appropriate material, that is, easy to read, when the tool has a value equal to or greater than $40 \%$ in relation to the total scores. The interpretation of the values obtained with FKR are: 75 - 100\% (very easy); 50 - 75\% (easy); 25 - 50\% (hard); $0-25 \%$ (very hard) $^{(18)}$. The analysis was performed by the program Microsoft Word version 2010.

The target audience assessed the booklet for organization, writing style, appearance, reading motivation ${ }^{(12)}$. For this, dichotomous answers of the type "yes" or "no" were used; "Easy to understand" or "hard to understand"; "clear" or "confusing"; "Interesting" or "uninteresting".

\section{Analysis of results, and statistics}

In the analysis stage of the tool by the content experts, the Content Validity Index (CVI) ${ }^{(19)}$ was used to verify their agreement. 
The result was obtained by dividing the number of concordant items of the experts, that is, the items they scored with scores 4 and 5 , by the total of items ${ }^{(20)}$. An index equal to or greater than $78 \%(\mathrm{CVl} \geq 0.78)$ was considered acceptable, both for the individual assessment of each item and for the booklet's overall assessment ${ }^{(19)}$.

The calculation of the tool score analyzed by the technical experts was adapted from the Suitability Assessment of Materials (SAM). In this analysis, it is possible to calculate the total adequacy score by summing the scores obtained, divided by the total number of questionnaire items and multiplied by 100 , to transform it into a percentage. The following results were found: $70-100 \%$ (superior material), $40-69 \%$ (appropriate material) or 0-39\% (inappropriate material)(17).

For data analysis with the target population, validated items were those with a level of agreement equal to or greater than $75 \%$ of positive responses. Positive answers were those that obtained the answers "yes", "easy to understand", "clear" and "interesting"(21).

Data were compiled in a Microsoft ${ }^{\circledR}$ Office 365 spreadsheet, version 1812, and, after coding and tabulation, analyzed using descriptive statistics. The suggestions of the experts, accepted by the researchers, were added in the final version of the booklet.

\section{RESULTS}

\section{Construction of the educational booklet}

The first step for the construction of the booklet corresponded to the literature review through an integrative literature review regarding care for children with gastrostomy. The search resulted in 307 articles by crossing the descriptors, but only five were included in the analysis. From the integrative review data, we identified the relevant items to compose the domains of the booklet, divided into: food care, medication, skin and catheter complications, such as granuloma, dermatitis and infection and device replacement.

In the situational diagnosis stage, it was identified that the 29 participating caregivers were mothers who accompanied their children and sought the service for the following reasons: catheter replacement by scheduling and/or balloon rupture/ connection rupture; complications such as granuloma, dermatitis, infection, ostium enlargement. All agreed to participate in the study and answered the questions of the tool. Data showed that they were between 18 and 43 years old, mostly single and with more than one child. As for children, most had a medical diagnosis of Ontogenetic Cerebral Dysmotria, and the duration of catheter use ranged from one month to six years. Participants reported doubts regarding the type of catheter; child care in feeding, bathing and complications such as granuloma, dermatitis, ostium enlargement, infection, and also how to proceed when the catheter was expelled from the ostium.

With these data, it was possible to identify the most relevant points to be included in the booklet and start the construction process. The information included was clear and objective and illustrative images were added to the booklet to facilitate understanding.

The first version constructed contained 18 pages, printed on $40 \mathrm{~kg}$ legal paper, A4 size $(210 \times 297)$. It was divided into ten domains (1. Gastrostomy; 2. Food Care; 3. Medications; 4. Skin Care; 5. Bath 6. Dressing 7. Granuloma 8. Accidental exit 9. Infection 10. Catheter replacement).
Although the booklet had a high agreement for the items, the suggestions of the experts in the first version, considered pertinent by the authors, to improve the content and appearance of the constructed material were accepted. The modifications made include: description of the catheter connections and their purpose; pool bath information; name the causes of dermatitis; improve cover image and enlarge the image of the catheter in children during bath add a domain about the activities of children with gastrostomy, bibliographic references and a space for notes.

After validation, upon expert consideration, the final version of the booklet resulted in 22 pages and 12 domains (1. What gastrostomy is, 2. Knowing the gastrostomy tube, 3. Care in feeding; 4. Care in the administration of medications; 5 . Bath care; 6 . Skin care; 7. Granuloma; 8. Dermatitis; 9. Infection; 10. Accidental exit of the probe; 11 . Changing the probe; 12 . Activities of children with gastrostomy). There was an increase in references used in material preparation, as well as a space for notes of caregivers.

\section{Booklet validation}

The educational booklet validation was performed with health professionals (content experts); communication area (technical experts) and caregivers of children with gastrostomy (target audience). Eighteen content experts participated, of which 15 were nurses, two doctors and a speech therapist, with an average age of 40 years and training time between five and 22 years. Regarding the academic profile, six (33.3\%) were doctors with theses in the area of child health and/or educational technologies. Regarding the content experts' score, the minimum and maximum scores were six and 13, respectively, out of a total of 15 points, considering them as experts for analysis.

The overall CVI, calculated based on the average of all items, scored 0.93, as shown in Table 1.

Of the five technical experts, three were journalists, one designer and one educator. The average age was 35 years. Three were professors and had experience with tool validation. The answers for this group were calculated using the SAM tool and an overall percentage of $85.2 \%$ was obtained, which allows us to assess the booklet as "superior material" according to the SAM and to consider it valid for this population.

The booklet's second version was sent for Portuguese proofreading. Then, the Readability Index was calculated, receiving an overall score of $72 \%$, which classified it as "easy", being understood by people with up to eight years of study.

The fifth step included validation with the target audience: ten caregiving mothers of children with gastrostomy who were with their children admitted to the study hospital. After consent to participate, they received the booklet and could handle it at the time they deemed necessary to respond to the tool only afterwards. The average time of each application was 45 minutes. It is noteworthy that the information collection took place at children's bedside, to prevent caregivers from being away from children for a long time. Regarding age, the average of the participants was 32.5 years, with an average education of nine years of study, eight of them married. Children's age ranged from three months to 12 years and the time of use of the gastrostomy catheter from 22 days to 11 years. 
Table 1 - Content validation of the booklet items "Cuidando da criança com gastrostomia", Fortaleza, Ceará, Brazil, 2018

\begin{tabular}{|c|c|c|}
\hline Booklet Assessment Criteria & $\mathrm{N}=18$ & CVI * \\
\hline \multicolumn{3}{|l|}{ Objectives } \\
\hline 1.1 The objectives are consistent with the health education needs of caregivers of children with gastrostomy. & 17 & 0.95 \\
\hline 1.2 The booklet is important for care for children with gastrostomy. & 18 & 1.00 \\
\hline 1.3 The information in the booklet instigates changes in caregiver behavior. & 15 & 0.86 \\
\hline 1.4 The booklet can circulate in the scientific area of the area. & 15 & 0.86 \\
\hline 1.5 The booklet meets the objectives of children's gastrostomy institutions. & 17 & 0.95 \\
\hline \multicolumn{3}{|l|}{ Structure and presentation } \\
\hline 2.1 The booklet is suitable for caregivers of children with gastrostomy. & 18 & 1.00 \\
\hline 2.2 The text is clear and objective. & 16 & 0.90 \\
\hline 2.3 The information is scientifically correct. & 18 & 1.00 \\
\hline 2.4 The material is appropriate to the sociocultural level of caregivers. & 15 & 0.86 \\
\hline 2.5 There is a logical sequence of the displayed content. & 16 & 0.90 \\
\hline 2.6 Information is structured in agreement and spelling. & 16 & 0.90 \\
\hline 2.7 The wording of the booklet corresponds to the level of knowledge of caregivers. & 15 & 0.86 \\
\hline 2.8 Information on the cover, back cover, summary, acknowledgments and/or presentation is consistent. & 16 & 0.90 \\
\hline 2.9 The size of the title and topics is adequate. & 17 & 0.95 \\
\hline 2.10 The illustrations are expressive and sufficient. & 16 & 0.90 \\
\hline 2.11 Printed material is appropriate. & 16 & 0.90 \\
\hline 2.12 The number of pages is adequate. & 16 & 0.90 \\
\hline \multicolumn{3}{|l|}{ Relevance } \\
\hline 3.1 The themes portray key points that should be reinforced in health education for caregivers. & 18 & 1.00 \\
\hline 3.2 The material allows the transfer and generalizations of learning to different contexts. & 17 & 0.95 \\
\hline 3.3 The booklet proposes the construction of knowledge for the caregiver. & 18 & 1.00 \\
\hline 3.4 The booklet addresses issues needed by caregivers of children with gastrostomy. & 18 & 1.00 \\
\hline 3.5 The booklet is suitable for use by any child caregiver with gastrostomy. & 17 & 0.95 \\
\hline
\end{tabular}

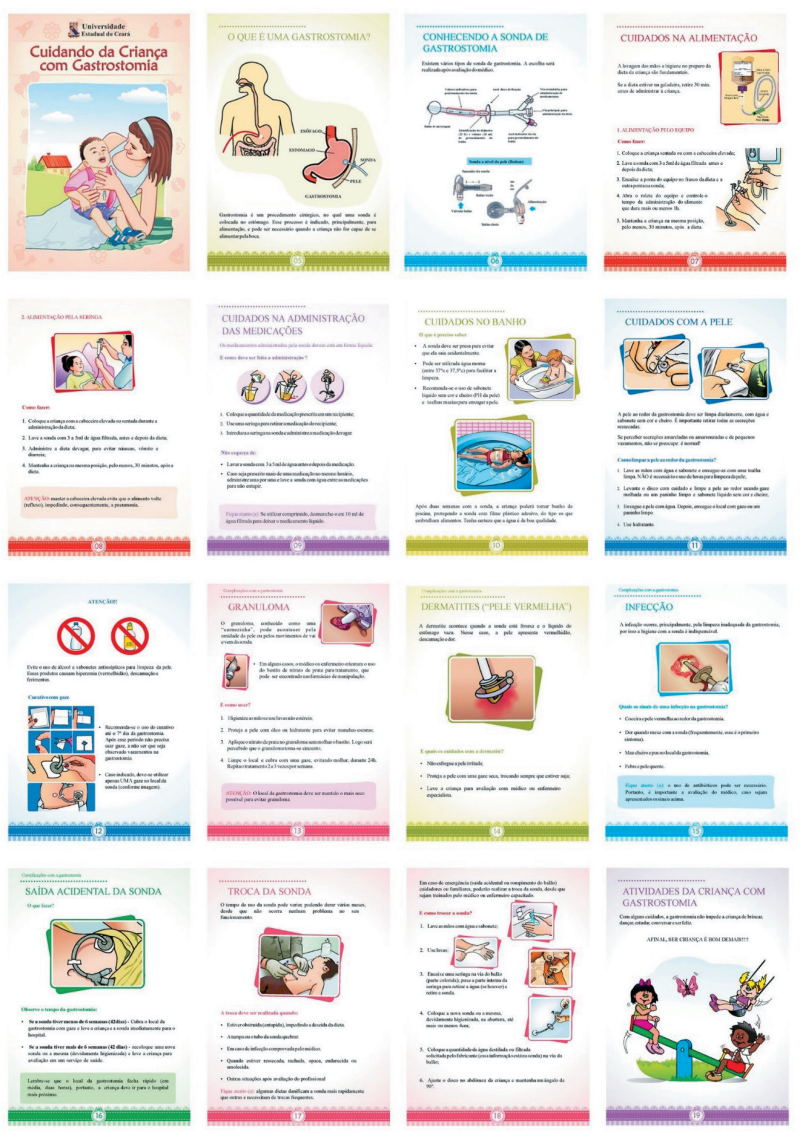

Figure 1 - Cover and pages of the booklet "Cuidando da criança com gastrostomia" (freely translated as caring for children with gastrostomy), Fortaleza, Ceará, Brazil, 2018
The tool used for the assessment with the target audience obtained $100 \%$ agreement level of positive answers, indicating clarity in the text and adequate illustrations. Thus, the booklet is considered relevant for application in the context of caregivers of children with gastrostomy.

Some mothers mentioned doubts about caring for their children with gastrostomy, especially regarding bathing, catheter administration, adequate time for catheter replacement, reasons for accidental discharge, and complications. These doubts were clarified by the researcher at the time of application of the booklet, being pointed as fundamental to improve child care. In the end, caregivers' opinion about the constructed material was questioned and all made favorable comments to the constructed technology, emphasizing that the language was accessible and the images understandable, helping them with children care. The booklet's final version consisted of 22 pages, 12 domains and called "Cuidando da criança com gastrostomia" (freely translated as caring for children with gastrostomy) (Figure 1).

\section{DISCUSSION}

Educational technologies have been used to improve the knowledge of health professionals and caregivers in their daily lives. This study aimed to build and validate a printed booklet, as it is a material that can be taken home and, therefore, more accessible to the target audience as a guide in child care. A similar study made available an illustrated booklet with pictures to the participants, justifying this option for the accessibility of the material to people of all educational levels $s^{(16)}$.

To build an educational material, it is necessary to know the context of the population to which it is intended, through a 
participative, communicative and collective approach in order to define care strategies ${ }^{(22)}$. Therefore, this study also considered the contribution of caregivers as a target audience to support the preparation of the booklet with vocabulary and easy-tounderstand illustrations. It is noteworthy that the word "catheter" was replaced by "probe" throughout the booklet, as it is the most widely used term and known among caregivers.

The collaboration of a design professional with extensive child imaging experience was essential to the look of the booklet. This professional contributed actively in editorial and diagramming work, since the beginning of the process, shaping the material built.

The participation of professionals from different areas of expertise in the validation process was another favorable aspect of the study, as it allowed to combine several specialized knowledge on the theme addressed. Recruiting experienced professionals from different areas ensures greater accuracy in the selection and assessment of educational materials, as well as valuing opinions and different approaches on the same subject ${ }^{(23)}$. Thus, the multidisciplinarity of experts with experience in teaching, research and assistance was essential for the booklet validation process, as well as the validation by the target audience.

In CVI assessment, the booklet domains always presented a score higher than the determined value, suggesting that the booklet is representative as to the content to be addressed about management with gastrostomy. In research conducted on technology assessment, other researchers also found CVI similar to that obtained in this study ${ }^{(24-25)}$. Regarding SAM score, it was observed that the booklet was higher than the established score, which shows agreement of the answers of the experts who assessed it.

Although the material was well assessed by the experts, observations and contributions recorded by them contributed to reformulate some information, replace terms, review illustrations. In this sense, they were essential to improve the quality of educational material for the target audience in the final version.

The degree of readability, performed after validation with experts, presented a satisfactory and consistent percentage for understanding the writing of the booklet, considering the explanatory technology, important and appropriate for the target audience who have up to eight years of study. Measuring the readability of an educational material is important to avoid learning limitations as a result of poor education. It can have its credibility and acceptance of educational technologies when there is the participation of experts and representatives of the target audience ${ }^{(17)}$.

Educational material validation with the population that somehow experiences the theme addressed in it needs to be considered in the development of educational technologies, being a necessary attitude and an important gain for the researcher and the staff involved ${ }^{(24)}$. It is still time to identify what is really missing, what was not understood, and the gap between what is written and what is actually understood, considering the patient and his family as the main focus of health education ${ }^{(25)}$. Thus, booklet assessment by caregivers showed that its content was written according to the reality of their lives, in view of the positive assessment they made of the material. In this sense, the participatory approach used during the situational diagnosis was fundamental because it allows the active contribution of caregivers in the identification of the domains of the booklet, so that they corresponded to their real daily needs.

\section{Study limitations}

As a limitation of the study is the difficulty in finding articles that address care provided to children with gastrostomy, both in national and international literature, especially regarding the productions in the last five years.

\section{Contributions to nursing and health}

It is believed that the study may contribute to care for children with gastrostomy, especially when caregivers have the booklet built in their homes, where doubts may arise more frequently. Therefore, it is expected that the built technology will be implemented in specialized services, with the support of government agencies for reproduction, dissemination and distribution of this material in the hospital.

\section{CONCLUSIONS}

The built-in booklet proved to be valid in terms of content and appearance. Besides the assessment of the items by the experts, they had the opportunity to make suggestions along the construction process. Therefore, it can be considered a tool capable of assisting caregivers in maintaining good practices in care for children with gastrostomy.

Performing such care is a complex activity that requires caregivers' knowledge to avoid catheter complications. It is noteworthy that although this study shows potentially satisfactory results for the use of the booklet, further research is needed to carefully assess the application processes of this technology, as well as long-term follow-up studies with caregivers of children with gastrostomy.

\section{FUNDING}

This study had financial support from Coordination for the $\mathrm{Im}$ provement of Higher Education Personnel - Coordenação de Aperfeiçoamento de Pessoal de Nível Superior).

\section{REFERENCES}

1. Kirk L, Shelley A, Battles M, Latty C. Educating Parents on Gastrostomy Devices: Necessary Components to Achieve Success. J Pediatr Nurs. 2014;29(1):457-65. doi: 10.1016/j.pedn.2014.05.002

2. Salvador MS, Gomes GC, Oliveira PK, Gomes VLO, Busanello J, Xavier DM. Strategies of families in the care of children with chronic diseases. Texto Contexto Enferm. 2015;24(3):662-9. doi: 10.1590/0104-07072015000300014 Portuguese. 
3. Rodrigues LN, Silva AMO, Xavier MS, Chaves EMC. Complications and cares related to the use of the gastrostomy tube in pediatrics. Braz. J. Enterostomal Ther. 2018;16(e1018):1-6. doi: 10.30886/estima.v16.464_PT Portuguese.

4. Mela CC, Zacarin CFL, Dupas G. Family evaluation of children and adolescentes submitted to gastrostomy. Rev Eletrônica Enferm. 2015;17(2):21222. doi: 10.5216/ree.v17i2.29049 Portuguese

5. Sevilla WM, McElhanon B. Optimizing Transition to Home Enteral Nutrition for Pediatric Patients. Nutr Clin Pract. 2016;31(6)2-7. doi: $10.1177 / 0884533616673348$

6. Berardinell LM, Guesdes NA, Ramos JP, Silva MG. Educational technology as a strategy for the empowerment of people with chronic illnesses. Rev Enferm UERJ. 2014;22(5):603-9. doi: 10.12957/reuerj.2014.15509 Portuguese.

7. Áfio A, Balbino A, Alves M, Carvalho L, Santos M, Oliveira N. Analysis of the concept of nursing educational technology applied to the patient. Rev Rene. 2014;15(1):158-65. doi: 10.15253/2175-6783.2014000100020 Portuguese.

8. Monteiro SNC, Carvalho EMP, Medeiros L, Silva AL, Guilhem D. Educação em saúde para crianças com estomias intestinais: o enfermeiro como mediador do cuidar. Rev Pesqui Qualit [Internet]. 2018 [cited 2019 Jan 26];6(10):44-59. Available from: https://editora.sepq.org.br/ index.php/rpq/article/view/205/105

9. Cucolo DF, Perroca MG. Instrument to assess the nursing care product: development and content Validation. Rev Latino-Am Enfermagem. 2015;23(4):642-705. doi: 10.1590/0104-1169.0448.2599 Portuguese.

10. Bezerra CM, Cardoso MVLML, Silva GRF, Rodrigues EC. Creation and validation of a checklist for blood transfusion in children. Rev Bras Enferm. 2018;71(6):3196-202. doi: 10.1590/0034-7167-2018-0098 Portuguese.

11. Mota FRN, Victor JF, Silva MJ, Bessa MEP, Amorim VL, Cavalcante ML, et al. Cross-cultural adaptation of the Caregiver Reaction Assessment for use in Brazil with informal caregivers of the elderly. Rev Esc Enferm USP. 2015;49(3):426-34. doi: 10.1590/S0080-623420150000300010 Portuguese.

12. Bispo GLR, Pedrosa EN, Wanderley RMM, Corrêa SMS. Development and validation of the nursing instrument to postpartum consultation. Rev Enferm UFPE. 2012;6(3):596-605. doi: 10.5205/reuol.2163-16218-1-LE.0603201214 Portuguese.

13. Lopes MVO, Silva VM, Araujo TL. Methods for Establishing the Accuracy of Clinical Indicators in Predicting Nursing Diagnoses. Int J Nurs Knowl. 2012;23(3):134-9. doi: 10.1111/j.2047-3095.2012.01213.x

14. Vinuto J. A amostragem em bola de neve na pesquisa qualitativa: um debate em aberto. Temáticas [Internet]. 2014 [cited 2019 Jan 26];22(44):203-20. Available from: https://www.ifch.unicamp.br/ojs/index.php/tematicas/article/view/2144/1637

15. Atran S, Medin DL, Ross NO. The cultural mind: Environmental decision making and cultural modeling within and across populations. Psychol Rev. 2005;112(4):744-76. doi: 10.1037/0033-295X.112.4.744

16. Oliveira SC, Lopes MVO, Fernandes AFC. Development and validation of an educational booklet for healthy eating during pregnancy. Rev Latino-Am Enfermagem. 2014;22(4):611-20. doi: 10.1590/0104-1169.3313.2459 Portuguese.

17. Sousa CS, Turrini RNT, Poveda VB. Translation and adaptation of the instrument "suitability assessment of materials" (SAM) into Portuguese. Rev Enferm UFPE [Internet]. 2015 [cited 2018 Dec 16];9(5):7854-61. Available from: https://periodicos.ufpe.br/revistas/revistaenfermagem/ article/view/10534/11435 Portuguese.

18. Teles LM, Oliveira AS, Campos FC, Lima TM, Costa CC, Gomes LF, et al. Development and validating an educational booklet for childbirth companions. Rev Esc Enferm USP. 2014;48(6):977-84. doi: 10.1590/S0080-623420140000700003 Portuguese.

19. Polit DF, Beck CT. Fundamentos de pesquisa em enfermagem: avaliação de evidências para a prática de enfermagem. 7.ed. Porto Alegre: Artmed, 2011.

20. Alexandre NMC, Coluci MZO. Validade de conteúdo nos processos de construção e adaptação de instrumentos de medidas. Ciênc Saúde Colet. 2011;16(7):3061-8. doi: 10.1590/S1413-81232011000800006

21. Lima MA, Pagliuca LM, Nascimento JC, Caetano JA. Virtual guide on ocular self-examination to support the self-care practice for people with hiv/aids. Rev Esc Enferm USP. 2014;48(2):285-91. doi: 10.1590/S0080-6234201400002000013 Portuguese.

22. Albuquerque AFLL, Pinheiro AKB, Linhares FMP, Guedes TG. Technology for self-care for ostomized women's sexual and reproductive health. Rev Bras Enferm. 2016;69(6):1099-106. doi: 10.1590/0034-7167-2016-0302 Portuguese.

23. Lima ACMAC, Bezerra KC, Sousa DMN, Rocha JF, Oriá MOB. Development and validation of a booklet for prevention of vertical HIV transmission. Rev Acta Paul Enferm. 2017;30(2):181-9. doi: 10.1590/1982-0194201700028 Portuguese.

24. Moura IH, Silva AFR, Rocha AESH, Lima LHO, Moreira TMM, Silva ARV. Construction and validation of educational materials for the prevention of metabolic syndrome in adolescents. Rev Latino-Am Enfermagem. 2017;25:e2934. doi: 10.1590/1518-8345.2024.2934 Portuguese.

25. Echer IC. The development of handbooks of health care guidelines. Rev Latino-Am Enfermagem. 2005;13(5):754-7. doi: 10.1590/S010411692005000500022 Portuguese. 